\title{
PENGARUH PEER GROUP TERHADAP INTENSITAS PERILAKU BULLYING PADA USIA ANAK
}

\author{
Hardiyanti Rahmah \\ Dosen, STIQ Amuntai, Kalimantan Selatan \\ Email : rahmah.anwar@yahoo.co.id
}

\begin{abstract}
Abstrak
Pada masa usia TK dan Sekolah Dasar adalah masa dimana anak belajar banyak hal berdasarkan pengalaman yang dilihat di lingkungannya, baik lingkungan rumah maupun sekolah. Saat usia anak ini, mereka belajar dengan cepat dari peer groupnya, baik itu pembelajaran yang positif maupun negatif, termasuk perilaku bullying yang dipelajari anak dari temannya kemudian diikutinya. Bullying merupakan bentuk perilaku kekerasan fisik dan kekerasan psikologis (verbal dan non verbal). Tujuan dari penelitian ini adalah untuk mengetahui pengaruh peer group terhadap perilaku bullying dan bagaimana dampaknya terhadap kesehatan mental. Penelitian ini menggunakan pendekatan kuantitatif.Subjek penelitian ini berjumlah 122 orang dengan rentang usia 8 - 12 tahun. Hasil penelitian menunjukkan bahwa nilai F sig. 0,022 lebih kecil dari taraf signifikansi $5 \%(0,022<0,05)$, sehingga disimpulkan peer group memberikan pengaruh terhadap munculnya perilaku bullying pada anak.
\end{abstract}

Kata Kunci :Peer Group, Bullying, Usia Anak

\section{A. Pendahuluan}

Selama bertahun-tahun bullying telah meningkat secara signfikan dan sejumlah besar anak di usia sekolah terlibat dalam bullying, baik sebagai korban maupun sebagai pelaku bullying itu sendiri. Beberapa penelitian telah menemukan dampak dari perilaku bullying yaitu munculnya gejala kecemasan dan depresi yang dilaporkan sendiri di kalangan anak hingga remaja ${ }^{1}$.

Perilaku bullying memberi dampak negatif terhadap kondisi psikologisanak yang menjadi korban bullyingdan menjadikan pembiasaan yang

${ }^{1}$ Porsteinsdóttir, E. Effects of bullying on symptoms of depression and anxiety, the importance of parental support.Thesis. (Reykjavik University : Haskolinn Reykjavik, 2014), h. 4.

Jurnal Ilmiah AL-MADRASAH, Vol. 3, No. 1, Juli-Desember 2018 
Hardiyanti Rahmah: Pengaruh Peer Group Terhadap Intensitas Perilaku Bullying pada Usia Anak

buruk terhadap pelaku bullying. Efek dari bullying pada proses pembelajaran serta pada perkembangan emosional anak-anak dan remaja sangat merusak ${ }^{2}$.

Fenomena bullying yang sering dijumpai adalah kondisi senioritas, yaitu adanya intimidasi siswa yang lebih senior terhadap adik kelasnya baik secara fisik atau psikis.Penelitian yang dilakukan di berbagai negara menunjukkan bahwa $8 \%$ hingga 38\% siswa menjadi korban bully.Secara global, sekitar 10\% hingga 27\% siswa dilaporkan sering menjadi korban bully. Di Indonesia, sekitar $84 \%$ siswa pernah mengalami kekerasan atau perilaku bullying yang dilakukan oleh teman sebayanya. Hasil penelitian terhadap sekitar 1.200 pelajar di Jakarta, Yogyakarta, dan Surabaya menunjukkan angka kejadian bullying sebesar 66,1\%. Yogyakarta mencatat angka tertinggi mengenai perilaku bullying di sekolah dibanding Jakarta dan Surabaya yaitu sebanyak $70,65 \% .^{3}$

Pada salah satu penelitian yang dilakukan terhadap kondisi psikologis pelaku dan korban bullying menunjukkan bahwa secara umum pelaku menunjukkan profil yang lebih positif dibandingkan dengan korban.Korban bullying menunjukkan profil kesehatan psikologis yang rendah.Pelaku bullying dalam tingkat kepercayaan diri cenderung memiliki kepercayaan diri yang lebih tinggi, adapun korbanbullying rasa tidak berdaya untuk melawan yang cenderung lebih tinggi. ${ }^{4}$

Berdasarkan pada beberapa hasil penelitian tersebut maka rumusan masalah pada penelitian ini adalah: Apakahpeer group dapat mempengaruhi peningkatan perilaku bullying pada usia anak? Tujuan dari penelitian ini adalah

\footnotetext{
${ }^{2}$ Papacostaa, S.E, Paradeisiotia, A. \& Lazaroua, C. Bullying phenomenon and preventive programs in Cyprus's school system.(International Journal of Mental Health Promotion, 16(1), 67-80, 2014), h.68.

${ }^{3}$ Rohimah, A. Hubunganperan kelompok teman sebaya dengan perilaku bullying pada anak usia sekolah di sd muhammadiyah mlangi gamping sleman yogyakarta. Skripsi.(Yogyakarta : Universitas Aisyiyah Yogyakarta, 2016), h. 5.

${ }^{4}$ Seixas, S. R, Coelho, J. P. \& Fischer, G.N. Bullies, victims and bully-victims impact on health profile.(Educacao, Sociedade \& Culturas, 38, 53-75, 2013), h. 54.
}

Jurnal Ilmiah AL-MADRASAH, Vol. 3, No. 1, Juli-Desember 2018 
Hardiyanti Rahmah: Pengaruh Peer Group Terhadap Intensitas Perilaku Bullying pada Usia Anak

mengetahui faktor-faktor pengaruh Peer Group Terhadap Intensitas Perilaku Bullying Pada Usia Anak.

\section{B. Metodologi Penelitian}

1. Rancangan Penelitian

Rancangan penelitian yang digunakan pada penelitian ini menggunakan desain kuantitatif, dengan tujuan untuk mengetahui pengaruh antara variabel $\mathrm{X}$ terhadap variabel $\mathrm{Y}$ dengan melakukan penyebaran angket atau skala pada subjek yang sudah ditentukan ${ }^{5}$. Angket yang sudah diiisi kemudian dikumpulkan kembali dan dilakukan perhitungan menggunakan metode regresi linier berganda. ${ }^{6}$

2. Subjek Penelitian

Subjek pada penelitian ini yaitu anak yang duduk di bangku Sekolah Dasar atau Madrasah Ibtidaiyah. Subjek penelitian dipilih dengan menggunakan teknik purposive sampling, yaitu cara pengambilan sampel secara sengaja, sesuai dengan persayaratan yang sudah ditentukan oleh peneliti ${ }^{7}$. Jumlah subjek sebanyak 122 orang terdiri dari usia 8-13 tahun, ketentuan subjek yaitu merupakan anak yang sudah bisa baca tulis dan memiliki peer group atau teman sebaya.

3. Variabel dan Instrumen Penelitian

Pada penelitian ini terdapat dua variabel yaitu peer group dan perilaku bullying. Variabel peer group merupakan variable bebas (X). Peer group adalah hubungan antar individu pada anak-anak atau remaja dengan tingkat usia yang sama serta melibatkan keakraban yang relatif besar dalam kelompoknya.

${ }^{5}$ Kerlinger, F. N. Asas-asas penelitian behavioral.(Jogjakarta: Gadjah Mada University Press, 2006), h. 233.

${ }^{6}$ Winarsunu, T. Statistik dalam penelitian psikologi dan pendidikan.(Malang: UMM Press, 2009), h. 93.

${ }^{7}$ Sugiyono. Metode penelitian pendidikan pendekatan kuantitatif, kualitatif dan $R \& D$.(Bandung: Alfabeta, 2011), h. 70.

Jurnal Ilmiah AL-MADRASAH, Vol. 3, No. 1, Juli-Desember 2018 
Hardiyanti Rahmah: Pengaruh Peer Group Terhadap Intensitas Perilaku Bullying pada Usia Anak

Perilaku bullying pada penelitian ini merupakan variable terikat (Y). Perilaku bullying yaitu suatu perilaku agresif yang berisfat negatif pada seseorang atau sekelompok orang yang dilakukan secara berulang-ulang dan dengan sengaja untuk menyakiti orang lain baik secara fisik atau mental karena adanya penyalahgunaan dan ketidakseimbangan kekuatan.

4. Validitas dan Reliabilitas Instrumen

Berdasarkan perhitungan SPSS untuk menguji validitas skala, item dapat dikatakan valid apabila $\mathrm{r}>0.30$ dan uji reliabilitas diukur dengan menggunakan Cronbach's alpha dimana hasil yang menunjukkan diatas 0,60 dapat dikatakan reliabel. ${ }^{8}$ Berikut adalah tabel validitas dan reliabilitas skala yang telah diujikan:

Tabel 1. Indeks Validitas dan Reliabilitas Alat Ukur Penelitian

\begin{tabular}{ccccc}
\hline Alat Ukur & $\begin{array}{c}\text { Jumlah Item } \\
\text { Diujikan }\end{array}$ & $\begin{array}{c}\text { Jumlah } \\
\text { Item Valid }\end{array}$ & $\begin{array}{c}\text { Indeks } \\
\text { Validitas }\end{array}$ & $\begin{array}{c}\text { Indeks } \\
\text { Reliabilitas }\end{array}$ \\
\hline $\begin{array}{c}\text { Skala Peer } \\
\text { Group }\end{array}$ & 15 & 9 & $0,300-0,459$ & 0,722 \\
$\begin{array}{c}\text { Skala } \\
\text { Bullying }\end{array}$ & 25 & 21 & $0,307-0,631$ & 0,839 \\
\hline
\end{tabular}

Berdasarkan hasil uji validitas yang telah dilakukan peneliti dari 40 item skala penelitian diketahui bahwa sebanyak 30 item skala dinyatakan valid, dengan rincian skala peer group berjumlah 9 item dan 21 item dari skala bullying. Sebelum digunakan untuk mengumpulkan data, instrument diujicobakan terlebih dahulu untuk mengetahui nilai reliabilitas dan validitasnya. Adapun nilai reliabilitas skala peer group setelah diujicobakan yaitu 0,722 dan nilai reliabilitas skala bullying setelah diujicobakan yaitu 0,839 yang berarti skala ini sangat reliabel untuk digunakan dalam penelitian.

\section{Prosedur dan Analisa Data}

Prosedur pada penelitian ini mengambil sampel penelitian dengan memilih subjek menggunakan teknik nonrandom sampling.Sampel subjek

\footnotetext{
${ }^{8}$ Sugiyono.Metode penelitian pendidikan pendekatan kuantitatif, kualitatif dan $R \& D$..., h. 76 .
}

Jurnal Ilmiah AL-MADRASAH, Vol. 3, No. 1, Juli-Desember 2018 
Hardiyanti Rahmah: Pengaruh Peer Group Terhadap Intensitas Perilaku Bullying pada Usia Anak

penelitian dipilih berdasarkan kriteria yang sudah ditentukan. ${ }^{9}$ Setelah melakukan penelitian, dilanjutkan proses analisa data hasil penelitian. Analisa data yang digunakan pada penelitian ini adalah analisa regresi yang merupakan teknik statistik untuk mengetahui pengaruh antara beberapa variabel. ${ }^{10}$

\section{Kajian Teori \\ 1. Peer group}

Istilah peer group atau biasa dikenal juga dengan kelompok teman sebaya merupakan sebuah hubungan yang berperan penting untuk perkembangan anak-anak. Teman sangat penting untuk perkembangan sosial, yaitu sebagai sarana belajar bagaimana bergaul dengan orang lain dan bagaimana mengajarkan anak terhadap kebutuhan struktur sosial yang lebih besar, serta untuk belajar bagaimana menerima bantuan dan dukungan, juga menyelaraskan diri dengan budaya yang lebih luas. Teman sebaya juga dianggap penting untuk perkembangan kognitif, afektif, dan perilaku. ${ }^{11}$

Interaksi pada kelompok sebaya merupakan proses kunci yang melaluinya anak-anak sangat mudah dipengaruhi, baik secara langsung oleh teman-temannya dan secara tidak langsung melalui norma, pendapat, dan pengalaman masyarakat luas. Peer group sebagai lingkungan sosial bagi anak berperan terhadap perkembangan kepribadian, yaitu untuk mengembangkan identitas diri serta mengembangkan kemampuan komunikasi interpersonal dalam pergaulan dengan kelompok teman sebaya. ${ }^{12}$

9 Darmawan, D.Metode penelitian kuantitatif. (Bandung: PT Remaja Rosdakarya, 2013), h. 72.

${ }^{10}$ Uyanto, S. S. Pedoman analisa data dengan SPSS. (Yogyakarta: Graha Ilmu, 2009), h. 65.

${ }^{11}$ Kindermann, Thomas. Peer Group Influences on Students' Academic Motivation.(Handbook On Social Influences On Social-Emotional, Motivation, And Cognitive Outcomes In School Contexts: Portland State University, 2015), h. 10.

${ }^{12}$ Wilson Dan. Peer Group Influences on Learning Outcomes. (Journal of Initial Teacher Inquiry, 2, 2016), h. 7.

Jurnal Ilmiah AL-MADRASAH, Vol. 3, No. 1, Juli-Desember 2018 
Hardiyanti Rahmah: Pengaruh Peer Group Terhadap Intensitas Perilaku Bullying pada Usia Anak

Peer group mampu memberikan dorongan baik positif ataupun negatif kepada anggota kelompoknya. Berdasarkan beberapa penelitian yang sudah digambarkan dukungan dari teman sebaya mampu meningkatkan prestasi anak, selain itu kelompok teman sebaya juga banyak yang menimbulkan perilaku negatif pada anak, salah satunya adalah perilaku bullying.

\section{Bullying}

Bullying merupakan bentuk perilaku negatif yang dilakukan berulang bertujuan menyebabkan ketidaksenangan atau menyakitkan kepada korban bully, baik satu atau beberapa orang secara langsung terhadap seseorang yang tidak mampu melawannya. Menurut American Psychiatric Association (APA) bullying adalah perilaku agresif yang dikarakteristikkan dengan 3 kondisi tertentu, yang pertama adalah adanya perilaku negatif yang bertujuan untuk merusak atau membahayakan, yang kedua perilaku yang diulang selama jangka waktu tertentu dan terakhir adanya ketidakseimbangan kekuatan atau kekuasaan dari pihak-pihak yang terlibat. ${ }^{13}$

Bullying atau penindasan adalah perilaku destruktif, yang biasanya pelakunya adalah siswa yang memiliki sifat agresi lebih tinggi daripada temannya. Ada banyak bentuk bullying seperti memanggil nama dengan mengejek, memukul atau mengancam orang lain dan menyebarkan desas-desus palsu. Menurut National Association of School Psychologists jejaring sosial dan pengiriman teks juga termasuk bentuk dari bullying.Mereka yang secara langsung atau tidak langsung terlibat dalam bullying berada pada peningkatan risiko perilaku bermasalah, pelaku pelecehan, dan sering absens dari sekolah.Dengan demikian, bullying menciptakan hambatan untuk belajar dengan hasil negatif pada pelajar maupun institusi. ${ }^{14}$

${ }^{13}$ Stein, et al. Adolescent male bullies, victims, and bully-victims: a comparison of psychosocial and behavioral characteristics.(Journal of Pediatric Psychology, 2006), h. 274.

${ }^{14}$ Jan, M.S.A. Bullying in Elementary Schools: Its Causes and Effects on Students.(Journal of Education and Practice. 43-57, 6, 19, 2015), h. 45.

Jurnal Ilmiah AL-MADRASAH, Vol. 3, No. 1, Juli-Desember 2018 
Hardiyanti Rahmah: Pengaruh Peer Group Terhadap Intensitas Perilaku Bullying pada Usia Anak

Bullying merupakan bentuk penindasan atau bentuk perilaku kekerasan yang dapat membangkitkan perilaku agresif yang disengaja dan terus-menerus terhadap orang lain, seperti pemukulan fisik, pelecehan verbal, penyebaran desas-desus palsu dan pengucilan sosial. Pelaku bullyingakan merasakan kepuasan dari kelemahan korban dan korbannya, secara fisik, psikologis, dan verbal. ${ }^{15}$

\section{Hasil Penelitian / Analisis}

Tabel 2.Nilai Mean dan Standar Deviasi

\begin{tabular}{cccc}
\hline & Mean & Std. Deviation & $\mathrm{N}$ \\
\hline Peer group & 22,48 & 3,235 & 122 \\
Bullying & 52,04 & 6,532 & 122 \\
\hline
\end{tabular}

Nilai mean atau rata-rata pada variabel $\mathrm{x}$ dan y masing sebesar 22,48 untuk variabel $\mathrm{x}$ dan 52,04 untuk variabel y. Adapun standar deviasi kedua variabel sebesar 3,235 untuk variabel $\mathrm{x}$ dan 6,532 untuk variabel $\mathrm{y}$.

Tabel 3. Hasil Uji Regresi

\begin{tabular}{ccccc}
\hline $\mathrm{R}$ & $\mathrm{r}$ Square & $\begin{array}{c}\text { Adjusted } \mathrm{r} \\
\text { Square }\end{array}$ & $\mathrm{F}$ & Sig \\
\hline 0,208 & 0,043 & 0,035 & 5,400 & 0,022 \\
\hline
\end{tabular}

Hasil penelitian menunjukkan tingkat signifikan 0,022 < 0,05(menggunakan taraf signifikansi 5\%) sehingga dapat disimpulkan penelitian ini signifikan berarti ada pengaruh positif antara dua variabel penelitian yaitu peer group dapat mempengaruhi tingkat bullying pada usia anak. Adapun koefiesien determinasi antara kedua variabel sebesar 0,043.

Sehingga dapat disimpulkan bahwa perilaku bullying pada anak usia sekolah yaitu yang bersekolah di Madrasah Ibtidaiyah salah satu faktor pengaruhnya adalah adanya dukungan atau disebabkan karena dorongan peer

\footnotetext{
${ }^{15}$ Papacostaa, S.E, Paradeisiotia, A. \& Lazaroua, C. Bullying phenomenon and preventive programs in Cyprus's school system, h. 68.
}

Jurnal Ilmiah AL-MADRASAH, Vol. 3, No. 1, Juli-Desember 2018 
Hardiyanti Rahmah: Pengaruh Peer Group Terhadap Intensitas Perilaku Bullying pada Usia Anak

group.Nilai $\mathrm{r}$ yang menunjukkan pengaruh antara variabel $\mathrm{X}$ terhadap variabel Y bisa dilihat pada gambar berikut:

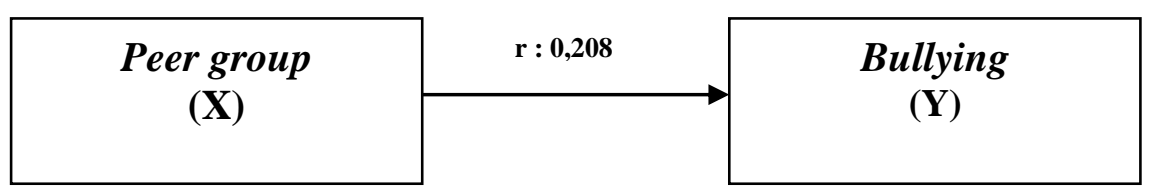

Gambar 1. Nilai $r$ variabel $\mathrm{X}$ terhadap $\mathrm{Y}$

\section{E. Pembahasan}

Berdasarkan hasil penelitian menunjukkan bahwa kelompok teman sebaya atau yang dikenal dengan istilah peer group memiliki pengaruh terhadap munculnya perilaku bullying pada usia anak. Penelitian ini sesuai dengan beberapa penelitian terdahulu, namun bedanya dengan penelitian-penelitian terdahulu adalah tingkat presentase pengaruh kelompok teman sebaya terhadap perilaku bullying anak sebesar 4,3\% saja dari $100 \%$, yang berarti $95,7 \%$ perilaku bullying dipengaruhi faktor-faktor lainnya. Presentase ini jauh dibawah presentase pada penelitian-penelitian terdahulu yang menunjukkan bahwa peer group memiliki pengaruh yang besar dalam membentuk perilaku bullying pada usia anak. Hal ini bisa saja disebabkan karena subjek penelitian yang merupakan siswa di Madrasah Ibtidaiyah yang mana pendidikan dan pengajarannya berbasis pada religiusitas atau nilai-nilai agama.

Bagi pelaku bully perilaku bullying pada usia anak dapat menjadi faktor pencetus perilaku-perilaku agresi yang lebih berbahaya ketika anak beranjak dewasa. Adapun bagi korban bully perilaku bullying yang dialaminya secara terus menerus akan menimbulkan berbagai masalah psikologis. Perilaku bullying merupakan masalah sosial yang sangat penting untuk dicegah dan diperbaiki, karena pelaku bully cenderung akan rendah prestasinya di bidang akademik. $^{16}$

${ }^{16} \mathrm{Al}$-Raqqad et al.The Impact of School Bullying On Students' Academic Achievement from Teachers Point of View.(International Education Studies, 2017), h. 46.

Jurnal Ilmiah AL-MADRASAH, Vol. 3, No. 1, Juli-Desember 2018 
Hardiyanti Rahmah: Pengaruh Peer Group Terhadap Intensitas Perilaku Bullying pada Usia Anak

Pada perilaku bullying anak cenderung berperilaku kasar, menyalahi aturan dan menyakiti orang lain baik melalui fisik atau psikis karena merasa memiliki kekuatan untuk menindas teman seusianya. Selain peer group banyak faktor lain yang juga dapat mempengaruhi meningkatnya perilaku bullying, seperti pengasuhan orang tua yang salah, kurangnya pendidikan moral dan lain sebagainya.

Kelompok teman sebaya atau peer group pada usia anak memberikan pengaruh yang sangat besar terhadap pembentukan perilaku anak, baik perilaku yang positif maupun negatif. Sehingga saat ada dukungan atau kompromi dari teman sebayanya dalam melakukan tindakan bullying,maka perilaku bullying tersebut akan menetap atau semakin meningkat intensitas perilakunya. Hal tersebut sesuai dengan hasil penelitian yang sudah dilakukan bahwa peer group memberi pengaruh atau dampak terhadap meningkatnya intensitas perilaku bullying pada usia anak.

\section{F. Simpulan}

Peer group merupakan kelompok teman sebaya yang terbentuk di dalam lingkungan sekolah atau lingkungan tempat tinggal berdasarkan usia, tingkatan kelas, hobi dan ketertarikan yang sama terhadap suatu hal. Perilaku bullying merupakan tindakan agresi yang bersifat negatif pada seseorang atau sekelompok orang yang dilakukan dengan sengaja untuk menyakiti secara fisik atau psikis. Berdasarkan hasil analisis data dan pengujian hipotesis, menunjukkan bahwa peer group menjadi salah satu faktor penyebab terjadinya perilaku bullying pada usia anak.

Jurnal Ilmiah AL-MADRASAH, Vol. 3, No. 1, Juli-Desember 2018 
Hardiyanti Rahmah: Pengaruh Peer Group Terhadap Intensitas Perilaku Bullying pada Usia Anak

\section{Daftar Pustaka}

Al-Raqqad et al.The Impact of School Bullying On Students' Academic Achievement from Teachers Point of View.International Education Studies, 10, 6, 44-50, 2017.

Darmawan, D.Metode penelitian kuantitatif.Bandung: PT Remaja Rosdakarya, 2013.

Jan, M.S.A. Bullying in Elementary Schools: Its Causes and Effects on Students.Journal of Education and Practice.43-57, 6, 19, 2015.

Kindermann, Thomas. Peer Group Influences on Students' Academic Motivation. Handbook On Social Influences On Social-Emotional, Motivation, And Cognitive Outcomes In School Contexts: Portland State University, 2015.

Rohimah, A. Hubunganperan kelompok teman sebaya dengan perilaku bullying pada anak usia sekolah di sd muhammadiyah mlangi gamping sleman yogyakarta. Skripsi.Yogyakarta : Universitas Aisyiyah Yogyakarta, 2016.

Papacostaa, S.E, Paradeisiotia, A. \& Lazaroua, C. Bullying phenomenon and preventive programs in Cyprus's school system. International Journal of Mental Health Promotion, 16(1), 67-80, 2014.

Porsteinsdóttir, E. Effects of bullying on symptoms of depression and anxiety, the importance of parental support.Thesis. (Reykjavik University : Haskolinn Reykjavik, 2014).

Seixas, S. R, Coelho, J. P. \& Fischer, G.N. Bullies, victims and bully-victims impact on health profile.Educacao, Sociedade \& Culturas, 38, 53-75, 2013.

Stein, et al. Adolescent male bullies, victims, and bully-victims: a comparison of psychosocial and behavioral characteristics. Journal of Pediatric Psychology, 2006.

Sugiyono. Metode penelitian pendidikan pendekatan kuantitatif, kualitatif dan R\&D. Bandung: Alfabeta, 2011.

Uyanto, S. S. Pedoman analisa data dengan SPSS. Yogyakarta: Graha Ilmu, 2009.

Wilson Dan. Peer Group Influences on Learning Outcomes.Journal of Initial Teacher Inquiry, 6-9, 2, 2016.

Jurnal Ilmiah AL-MADRASAH, Vol. 3, No. 1, Juli-Desember 2018 